\section{Exacerbation of Goodpasture's syndrome after inadvertent exposure to hydrocarbon fumes}

Circumstantial evidence suggests that an association exists between Goodpasture's syndrome and exposure to hydrocarbon fumes, but this exposure has been either heavy industrial exposure ${ }^{1-3}$ or due to abuse of hydrocarbon products. ${ }^{4}$ We report a case indicating that Goodpasture's syndrome may occur in seemingly benign environments and may be reactivated by further exposure to hydrocarbons.

\section{Case report}

A 16 year old girl presented with a cough of six weeks' duration and haemoptysis and dyspnoea of nine days' duration. For 10 months she had worked as a clerk in the printing department of a bank, where she was exposed to methylene chloride and $1,1,1$ trichloroethane when the printing machine was cleaned. There had been no exhaust ventilation.

On admission she was pale and scattered expiratory crepitations were noted. She was anaemic (haemoglobin $8.5 \mathrm{~g} / \mathrm{dl}$, normocytic, normochromic) with lymphocytopenia (731 with white cell count $\left.4.3 \times 10^{9} / 1\right)$ and renal impairment (creatinine concentration $0.11 \mathrm{mmol} / 1(1.24 \mathrm{mg} / 100 \mathrm{ml})$, urea $6.0 \mathrm{mmol} / 1(35.9 \mathrm{mg} / 100 \mathrm{ml})$, and creatinine clearance $\left.53 \mathrm{ml} / \mathrm{min} / 1.73 \mathrm{~m}^{2}\right)$. Microscopy of centrifuged urine showed 25000 red cells/ml (normal $<500$ ), 105 red cell casts $/ \mathrm{ml}$, and 45 granular casts $/ \mathrm{ml}$. Urinary protein excretion was $1.03 \mathrm{~g} / 24 \mathrm{~h}$. Results of intravenous pyelography were normal. Chest $x$ ray examination showed a diffuse pulmonary infiltrate. Arterial blood gas tensions (room air) were $\mathrm{pH} 7 \cdot 45$, arterial oxygen pressure $11.9 \mathrm{kPa}(89 \mathrm{~mm} \mathrm{Hg})$, and arterial carbon dioxide pressure $5.1 \mathrm{kPa}(38$ $\mathrm{mm} \mathrm{Hg})$. Forced expiratory volume in one second was $2 \cdot 31(92 \%$ of predicted value) and vital capacity 2.41 ( $78 \%$ of predicted). Single breath carbon monoxide pulmonary diffusing capacity was $73.6 \%$, and alveolar-arterial oxygen tension difference was $5.9 \mathrm{kPa}(44 \mathrm{~mm} \mathrm{Hg})$ (normal $1.6 \mathrm{kPa}(12$ $\mathrm{mm} \mathrm{Hg}$ )). Antiglomerular basement membrane antibody was present in serum; results of blood immunology tests were otherwise normal, and infection titres were insignificant. HLA typing yielded A1, A11, Bw39, B7, and DR4.

Renal biopsy findings included focal fibrinoid necrosis, one capsular adhesion, and one focal crescent out of 40 glomeruli, with bright linear IgG and moderate linear complement on immunofluorescence. By day six, after treatment with methylprednisolone $1 \mathrm{~g}$ /day for three days followed by prednisone $120 \mathrm{mg} / \mathrm{day}$, cyclophosphamide $2 \mathrm{mg} / \mathrm{kg} / \mathrm{day}$, and blood transfusion, chest $x$ ray appearances had returned to normal. Creatinine clearance improved to $103 \mathrm{ml} / \mathrm{min} / 1.73 \mathrm{~m}^{2}$ by day 14 , but 24 hour urinary protein loss was $1.5 \mathrm{~g}$ and carbon monoxide diffusing capacity was $58 \%$ and alveolar arterial oxygen tension difference was $4 \cdot 4 \mathrm{kPa}(33 \mathrm{~mm} \mathrm{Hg})$ on day 14 , when she was discharged.

Ten days after discharge and two days after inhaling an insect spray she presented again with bilateral loin pain and macroscopic haematuria. Haemoglobin concentration was $10.3 \mathrm{~g} / \mathrm{dl}$, creatinine concentration $0 \cdot 15$ $\mathrm{mmol} / 1(1.69 \mathrm{mg} / 100 \mathrm{ml})$, creatinine clearance $55 \mathrm{ml} / \mathrm{min} / 1.73 \mathrm{~m}^{2}$, urinary protein $3 \cdot 9-5 \cdot 4 \mathrm{~g} / 24 \mathrm{~h}$, and carbon monoxide pulmonary diffusing capacity $50 \%$; arterial blood gas tensions, chest $x$ ray appearances, and results of spirometry remained normal. Renal biopsy showed more extensive and prevalent focal necrotising glomerulonephritis with crescents. Immunofluorescence findings were unchanged.

Methylprednisolone $1 \mathrm{~g}$ was administered, prednisone $120 \mathrm{mg}$ /day and cyclophosphamide were continued, and 12 plasma exchanges of two litres each were performed over three weeks. Symptoms subsided within three weeks, and antiglomerular basement membrane antibody was persistently absent after the eleventh plasma exchange. Eighe weeks after the start of plasma exchange the creatinine clearance was $114 \mathrm{ml} / \mathrm{min} / 1 \cdot 73 \mathrm{~m}^{2}$, urine protein $2.3 \mathrm{~g} / 24 \mathrm{~h}$, and creatinine $0.09 \mathrm{mmol} / 1(1.02 \mathrm{mg} / 100 \mathrm{ml})$ and urine microscopy showed 24000 red cells and 15 hyaline casts $/ \mathrm{ml}$.

\section{Comment}

This report shows the association between exposure to hydrocarbon fumes and Goodpasture's syndrome. This association is further suggested by exacerbation of disease activity in this patient after inadvertent rechallenge with inhaled hydrocarbons. The initial hydrocarbon exposure was seemingly inconsequential and shows that a careful search of the working and home environments is necessary in all patients with Goodpasture's syndrome.

Exacerbation of symptoms in this girl occurred after inhalation at home of an insect killer that contained trichloroethane, and, although this does not prove cause and effect, there was no other apparent cause for this exacerbation. A subsequent investigation of non-listed components of many domestic products showed that almost all aerosols contain trichloroethane and, moreover, that methylene chloride is used to decaffeinate coffee in Australia. Hydrocarbons are thus readily available, and as they may exacerbate Goodpasture's syndrome inhalation of all products containing hydrocarbons, particularly aerosols, should be avoided by patients with the disease, particularly in its early phase.

We thank Dr J V Wells for performing immunofluorescence and Dr C Lauer for light microscopy reporting.

${ }^{1}$ Beirne GJ, Brennan JT. Glomerulonephritis associated with hydrocarbon solvents. Arch Environ Health 1972;25:365-9.

2 Proskey AJ, Weatherbee L, Easterling RE, Greene JA, Weller JM. Goodpasture's syndrome: a report of five cases and review of the literature. $A m \mathcal{F}$ Med $1970 ; 48: 162-73$.

${ }^{3}$ Zimmerman SW, Groehler K, Beirne GJ. Hydrocarbon exposure and chronic glomerulonephritis. Lancet 1975;ii:199-201.

4 Nathan AW, Toseland PA. Goodpasture's syndrome and trichloroethane intoxication. Br $\mathcal{F}$ Clin Pharmacol 1979;8:284-6.

(Accepted 12 fuly 1983)

Royal North Shore Hospital, St Leonard's, New South Wales, Australia

ANNE M KEOGH, MB, BS, medical registrar

LLOYD S IBELS, MB, FRACP, nephrologist

DAVID H ALLEN, PHD, FRACP, respiratory physician

JAMES P ISBISTER, FRACP, FRCPA, haematologist

Manly District Hospital, Manly, New South Wales

MICHAEL C KENNEDY, MD, FRACP, physician

Correspondence to: Dr L S Ibels, North Shore Medical Centre, St Leonards 2065, New South Wales, Australia.

\section{Potentiation of oral anticoagulants by ketoconazole}

The oral antifungal agent ketoconazole (Nizoral) has been available for the past two to three years. Currently the manufacturer's data sheet gives no reference to potential interaction of this drug with oral anticoagulants. I report a case in which treatment with ketoconazole potentiated the anticoagulant effect of warfarin.

\section{Case report}

A 75 year old woman had been treated with warfarin for three years. In 1976 she had suffered a myocardial infarction complicated by a pulmonary embolism, after which she received three months' treatment with warfarin. In 1980, after an episode of chest pain and dyspnoea, recurrent pulmonary emboli were diagnosed and confirmed by ventilation and perfusion scanning. She was given anticoagulant drugs and it was decided to continue these indefinitely. Anticoagulant control presented no major problem, with her British comparative ratio staying in the range 1-6-3.5. Minor adjustments were made to the dosage of warfarin, and the average weekly dosage ranged from 17 to $24 \mathrm{mg}$.

In March 1983 her general practitioner prescribed ketoconazole $200 \mathrm{mg}$ twice daily for a chronic vaginal thrush infection. The blood clotting ratio two days after ketoconazole was started was 1.9 ; her average weekly dosage of warfarin was $19 \mathrm{mg}$ and had been unchanged for the previous 13 months. After three weeks' treatment with ketoconazole she complained of spontaneous bruising and reported to the clinic, where her British comparative ratio was found to be $5 \cdot 4$. Full blood count, platelet count, and liver function tests gave normal results. Treatment with ketoconazole was stopped and warfarin dosage reduced. She was not receiving any other drugs. Over the next three weeks her warfarin control was restabilised at previous levels.

\section{Comment}

In this case no other drug was taken and ketoconazole is therefore clearly implicated in potentiating the effect of warfarin. An extensive list of drugs capable of interacting with warfarin was recently re- 